\title{
Structure of pond vegetation of a vereda in the Brazilian Cerrado
} Estrutura da vegetação de lagoa associada à vereda no Cerrado brasileiro

\author{
Suzana Neves Moreira ${ }^{2}$, Arnildo Pott ${ }^{2,3}$, Vali Joana Pott ${ }^{2}$ \& Geraldo Alves Damasceno-Junior ${ }^{2}$
}

\begin{abstract}
This is the first report on aquatic macrophytes in ponds of veredas (palm swamps) in the Cerrado (Brazilian savanna). We studied a pond in a vereda in Terenos, Mato Grosso do Sul state, central-western Brazil, during drought and flood periods to assess plant community structure and the relationship between species distribution and water depth. Sampling was carried out in five permanent transects, along which we placed sampling units of $1 \mathrm{~m}^{2}$ quadrats every $5 \mathrm{~m}$. We estimated visually the relative cover of each species, bare ground, dead matter, and exposed water. We also measured water depth. We recorded 77 species of 49 genera and 31 families. The number of species varied between seasons, and in the rainy season the amphibious life form was predominant. The richest families were Poaceae (15 species), Cyperaceae (11), Asteraceae (4) and Lentibulariaceae (4). The richest genera were Rhynchospora (4), Utricularia (4), Eleocharis (4), Aeschynomene (3), Bacopa (3), Ludwigia (3) and Panicum (3). We found six new occurrences for the cerrado. Eleocharis acutangula had the highest relative cover (rainy and dry seasons), followed by Bacopa reflexa (rainy season), Paspalum lenticulare (rainy and dry seasons), Leersia hexandra (rainy and dry seasons), and Sagittaria rhombifolia (rainy season). Some species were distributed mainly at shallower depths, others occurred in deeper water, whereas some species varied greatly in terms of depth. Heliotropium filiforme and Ludwigia nervosa were found only in the dry season. In the rainy season, as expected, the exclusive species were mostly true aquatics.
\end{abstract}

Key words: aquatic macrophytes, aquatic vegetation, phytosociology, temporary pond.

\section{Resumo}

Este é o primeiro levantamento de macrófitas aquáticas em lagoa de Vereda. Foi estudada uma lagoa associada à Vereda em Terenos, MS, em períodos de seca e cheia, para avaliar a estrutura das comunidades vegetais e a relação entre distribuição das espécies e a profundidade da água. A amostragem foi realizada em cinco transecções permanentes, ao longo das quais, a cada $5 \mathrm{~m}$, foram dispostas unidade amostrais de $1 \mathrm{~m}^{2} \mathrm{e}$ estimada visualmente a cobertura por espécie, solo exposto, material morto, água exposta e profundidade da água. Houve variação no número de espécies entre os períodos seco e chuvoso, no qual a forma de vida predominante foi anfíbia. Foram registradas 77 espécies, 49 gêneros e 31 famílias. As famílias com maior riqueza foram Poaceae (15 espécies), Cyperaceae (11) e Asteraceae e Lentibulariaceae (4) e os gêneros mais ricos, Rhynchospora, Utricularia e Eleocharis (4) e Aeschynomene, Bacopa, Ludwigia e Panicum (3). São mencionadas seis novas ocorrências em relação à última listagem da flora do Cerrado. Eleocharis acutangula foi a espécie com maior cobertura (cheia e seca), seguida por Bacopa reflexa (cheia), Paspalum lenticulare (cheia e seca), Leersia hexandra (cheia e seca) e Sagittaria rhombifolia (cheia e seca). Algumas espécies distribuem-se preferencialmente em profundidades menores, outras em locais mais profundos e algumas não tem padrão. Heliotropium filiforme e Ludwigia nervosa foram as únicas espécies encontradas apenas no período seco, enquanto no período chuvoso, como esperado, as espécies exclusivas foram, na sua maioria, as verdadeiramente aquáticas.

Palavras-chave: fitossociologia, lagoa temporária, macrófita aquática, vegetação aquática.

\footnotetext{
'Part of Master's thesis of the first author.

${ }^{2}$ Universidade Federal de Mato Grosso do Sul, UFMS, Programa em Pós-graduação em Biologia Vegetal, Cidade Universitária s/nº , 79070-900, Campo Grande, MS, Brazil. ${ }^{3}$ Corresponding author: arnildo.pott@gmail.com
} 


\section{Introduction}

Brazil has the world's largest hydrographic network, where aquatic ecosystems (riverine and lacustrine, permanent and seasonal) are well represented within biomes (Bove et al. 2003). The Cerrado (Brazilian savanna) is a water-rich biome, which harbors the headwaters of important rivers such as those of the upper Paraguay River Basin, where the Pantanal is located (Pott et al. 2011), and also many discrete but not less relevant swamps and seasonal water bodies.

Temporary aquatic environments, such as swamps, undergo seasonal dry periods and are flooded during rainy seasons (Gil \& Bove 2004). In these environments the vegetation is tolerant or adapted to wet soils and it undergoes seasonal flooding (Esteves 1998). Temporary ponds are closed depressions with herbaceous and subshrubby vegetation, which accumulate water during the rainy season (Pott $\&$ Pott 2000). The vegetation associated with these ecosystems comprises not only true aquatic plants, but also different kinds of periodically submersed plants or plants that grow on the shores of these habitats, such as amphibious species (Pott et al. 1992).

The ability to periodically alternate between terrestrial and aquatic phases is the most important feature of organisms from floodable areas (Junk et al. 1989). The hydrologic regime and differences in water depth are responsible for most patterns of species distribution in swamps (Casanova \& Brock 2000; Keddy 2000). According to Meirelles et al. (2002), there are distinct ecological groups related to the species' tolerance of different flood levels.

In the veredas (palm swamps dominated by the buriti palm Mauritia flexuosa L.f.) ponds are often formed, mainly due to natural blocking of drainage or to artificial impounding, and they have been reported in landscape descriptions of wet habitats in the Cerrado, sometimes even in papers on the fauna (e.g. Sousa \& ElmoorLoureiro 2008). Rosa (1956) cited such ponds in his famous novel 'Grande Sertão: Veredas'. However, we did not find published studies on the aquatic vegetation of vereda ponds. Therefore, the aim of this study was to evaluate the floristic and phytosociological structure of the vegetation of a vereda pond, under the assumption that water depth interferes with patterns of life form and species distributions.

\section{Material and Methods}

\section{Study area}

Field work was carried out in a pond of a vereda (20³3'34.5'S; 5447'21.7'”W, $550 \mathrm{~m}$ a.s.l.), in the headwaters of an affluent of Embiruçu Stream, located at Fazenda Modelo, Embrapa Gado de Corte, $11 \mathrm{~km}$ east of the road BR-262, Terenos municipality, near Campo Grande (state of Mato Grosso do Sul, Brazil); the climate is classified as Aw in Köppen's system (1984).

The pond covers approximately $400 \times 200 \mathrm{~m}$; the lower part was cut by the Novoeste railway around 1935, which caused partial damming that seems to be confined to the nearby borrow pit. The surroundings are composed of pastures, mainly of Urochloa spp. and Paspalum notatum Alain ex Flüggé (Poaceae); the original vegetation was cerrado, of which a fragment remains on a lateritic outcrop with an adjacent stripe of a waterlogged forest at the head of the connected vereda. Cows and horses have free access to the vereda, especially on the edges and trails, where they drink water and graze inside the pond bed during the dry season. The pond has gley soil; latosol prevails in the surroundings.

Monthly rainfall data from 2009-2010 were obtained from the weather station of Universidade para o Desenvolvimento do Estado e da Região do Pantanal (UNIDERP - Anhanguera) $\left(20^{\circ} 26^{\prime} 18^{\prime \prime} \mathrm{S}\right.$ and $54^{\circ} 32^{\prime} 18^{\prime \prime} \mathrm{W}$ ), located $30 \mathrm{~km}$ from our study area. Rainfall was $309.7 \mathrm{mmin}$ December 2009 and January 2010 (rainy period) and $123 \mathrm{~mm}$ in September 2010 (dry season). According to the weather station, 2009 was the rainiest year of the past 15 years in Campo Grande, $31 \%$ above mean annual rainfall $(1,429 \mathrm{~mm})$. We observed in the study area $(8 \mathrm{ha})$ that the water level rose $20 \mathrm{~cm}$ overnight, due to rainstorms in December.

\section{Sampling}

The phytosociological survey was carried out in December 2009 and January 2010 (rainy season) and in September 2010 (dry season). We set up five permanent transects, four of them disposed as an umbrella close to a deep smaller pond, where the transect was divided into four short parallel sections. We sampled 229 plots, marked with pegs along transects, which were 200 to $245 \mathrm{~m}$ long. Transects started after an edge of Andropogon bicornis (Poaceae), which indicates the external limit of the pond.

Every $5 \mathrm{~m}$ along the transects we placed sampling units of $1 \mathrm{~m}^{2}$ PVC quadrats. We estimated relative cover (vertical projection) of each plant species visually, as well as that of bare soil, dead 
material and open water. In each $1 \mathrm{~m}^{2}$ quadrat a central line was set up using a ruler and dividing the quadrat in two halves; another imaginary line was drawn, dividing the quadrat into quarters for estimating relative cover. Estimates were always made by the same two persons. We measured water depth in each quadrat (in $\mathrm{cm}$ ), using a ruler. Depths were adjusted to the highest level, which occurred on 26 January 2010.

Reproductive specimens were collected and deposited in the CGMS Herbarium of Universidade Federal de Mato Grosso do Sul, and non-reproductive plants were taken to the greenhouse to flower in order to allow taxonomic identification. Identification was made using the specialized literature, by comparison with herbarium specimens, and with the assistance of specialists. Angiosperm families followed APG III (2009) and for plant names we consulted the database Tropicos (2010); the nomenclature of Pteridophyta followed Tryon \& Tryon (1982), and the nomenclature of Characeae followed Krause (1997). Species were classified in life forms according to habit and position in relation to water surface (emergent, amphibious, freefloating, rooted floating, free submersed, rooted submersed and epiphytic) (Irgang et al. 1984). For species that showed more than one life form, we considered the dominant life form found in the study area.

Absolute and relative values of frequency and cover, and importance value (IV) were calculated following Brower \& Zar (1984) and Meirelles (2002). To assess floristic similarity between seasons we used the Sørensen index (Mueller-Dombois \& Ellenberg 1974). We used the Shannon index (H' - base e) to measure species diversity, based on relative cover instead of number of individuals (Kent \& Coker 1992).

We used ordination to assess species distribution along the environmental gradient (water depth). Using R (R Development Core Team 2009) and the Generic function, the matrices were built based on relative cover per species in each plot according to the depth gradient. In the Detrended Correspondence Analysis (DCA) calculated by the program PCOrd (Brower \& Zar 1984), the frequency distribution was calculated with the sum of relative cover of individuals in the plots per depth class. The total for each depth class was normalized to $100 \%$ to avoid unbalancing caused by differences in number of plots.

\section{Results and Discussion}

We found five of the seven life forms proposed by Irgang et al. (1984). We did not observe the free-floating life form, as in Pistia stratiotes L. and Salvinia spp. (Araceae), and the epiphytic life form, as in Oxycaryum cubense (Poepp. \& Kunth) Palla, which are common in the Pantanal (Pott \& Pott 2003). Of all sampled species, $64.5 \%$ were amphibious, $10.5 \%$ were rooted submersed, $9.2 \%$ were emergent, $9.2 \%$ were rooted floating, and $6.5 \%$ were free submersed species (Tab. 1). In the surveys carried out by Pott et al. $(1989,1992)$ and Pott \& Pott $(2003)$ in ponds of the Pantanal, the most expressive life form was emergent (varying from $51.42 \%$ to $39 \%$ ), followed by amphibious (28-20\%), and free-floating (21.4\%). The higher richness of amphibious plants in the studied pond compared to the Pantanal could be explained by their ability to live in flooded and dry areas. We did not find published data on life forms of aquatic plants in veredas.

We recorded 77 species in 49 genera and 31 families. Only six species were found outside plots (Tab. 1). Most families (51.6\%) and genera (65.3\%) were represented by a single species, indicating high richness and generic diversity in the study area. The families with the highest richness were Poaceae (15 species), Cyperaceae (11), Lentibulariaceae (5) and Asteraceae (4), corresponding to $47.9 \%$ of all families (Fig. 1). The richest genera were Utricularia (5 species), Rhynchospora and Eleocharis (4 species each) and Aeschynomene, Bacopa, Panicum and Ludwigia (3 species each) (Tab. 1). We found six species that were not included on the Cerrado flora checklist (Sano et al. 2008): Mandevilla widgrenii, Panicum pedersenii, Paspalum lenticulare, Schwenckia juncoides, Utricularia olicacea and Widgrenia corymbosa, and this corroborates our idea that vereda ponds are relatively unknown habitats.

Poaceae, Cyperaceae and Asteraceae also showed high richness in other studies in Cerrado swamps (Munhoz \& Felfili 2008; Oliveira et al. 2009; Guimarães et al. 2002; Araújo et al. 2002; Meirelles et al. 2004). These families were responsible for the high representativeness of the herbaceous stratum in the pond, what can be explained by the excess of water selecting more efficient species under particular edaphic conditions, which hinder woody strata, according to Araújo et al. (2002).

In the rainy season, when flooding occurs, relative cover (RC) of the 10 main species was $65.9 \%$ 
Table 1-Families and species sampled in a pond associated to vereda, Terenos, MS, Brazil, in flood and dry seasons. $\mathrm{RC}=$ relative cover and $\mathrm{RF}=$ relative frequency. In bold the species with highest $\mathrm{RC}$ and $\mathrm{RF}$ per sampling period. Life forms: $\mathrm{A}=$ amphibious, $\mathrm{E}=$ emergent, $\mathrm{FF}=$ rooted floating, $\mathrm{SF}=$ rooted submerse and $\mathrm{SL}=$ free submerse. $*=\mathrm{Species}$ recorded outside plots.

\begin{tabular}{|c|c|c|c|c|c|c|}
\hline \multirow[t]{2}{*}{ Family } & \multirow[t]{2}{*}{ Species } & \multirow[t]{2}{*}{$\begin{array}{l}\text { Life } \\
\text { Form }\end{array}$} & \multicolumn{2}{|c|}{$\begin{array}{l}\text { Flood } \\
\text { Season }\end{array}$} & \multicolumn{2}{|c|}{$\begin{array}{c}\text { Dry } \\
\text { Season }\end{array}$} \\
\hline & & & $\mathbf{R C}$ & RF & $\mathbf{R C}$ & RF \\
\hline \multirow[t]{3}{*}{ ALISMATACEAE } & Echinodorus tenellus & A & 0.85 & 1.37 & 5.26 & 5.54 \\
\hline & (Mart. ex Schult. \& Schult. f.) Buchenau & & & & & \\
\hline & Sagittaria rhombifolia Cham. & $\mathrm{FF}$ & 3.99 & 7.04 & 3.43 & 6.85 \\
\hline \multirow[t]{2}{*}{ APIACEAE } & Eryngium ebracteatum Lam. & $\mathrm{A} / \mathrm{E}$ & 0.12 & 0.13 & 0.08 & 0.09 \\
\hline & E. pandanifolium Cham. \& Schltdl. & $\mathrm{A} / \mathrm{E}$ & 0.56 & 0.46 & 0.88 & 0.62 \\
\hline \multirow[t]{2}{*}{ APOCYNACEAE } & * Mandevilla widgrenii C. Ezcurra & A & . & . & . & . \\
\hline & Widgrenia corymbosa Malme & $\mathrm{A} / \mathrm{E}$ & 0.02 & 0.26 & . & . \\
\hline ARALIACEAE & Hydrocotyle ranunculoides L.f. & $\mathrm{FF}$ & 0.28 & 0.85 & 0.28 & 0.53 \\
\hline \multirow[t]{4}{*}{ ASTERACEAE } & Mikania micrantha Kunth & $\mathrm{E}$ & 0.22 & 0.07 & 0.1 & 0.18 \\
\hline & M. stenophylla Holmes & $\mathrm{E} / \mathrm{A}$ & 0.68 & 1.43 & 1.01 & 1.58 \\
\hline & Vernonia echitifolia Mart. ex DC. & A & 0.16 & 0.2 & 0.36 & 0.7 \\
\hline & V. rubricaulis Bonpl. & A & 0.49 & 1.3 & 0.44 & 0.79 \\
\hline BORAGINACEAE & Heliotropium filiforme Lehm. & . & . & . & 3.83 & 5.18 \\
\hline CABOMBACEAE & Cabomba furcata Schult. \& Schult. f. & SF & 1.52 & 0.52 & . & . \\
\hline \multirow[t]{3}{*}{ CHARACEAE } & * Chara guairensis $\mathrm{R}$. Bicudo & SF & . & . & . & . \\
\hline & Nitella flagellifera J.Groves \& G.O.Allen & SF & 0.39 & 0.98 & . & . \\
\hline & * N. subglomerata A.Braun & $\mathrm{SF}$ & . & . & . & . \\
\hline COMMELINACEAE & Floscopa cf. glabrata (Kunth) Hassk. & A & 0.22 & 0.59 & 0.5 & 0.62 \\
\hline \multirow[t]{11}{*}{ CYPERACEAE } & Cyperus haspan $\mathrm{L}$. & A & 0.02 & 0.07 & . & . \\
\hline & Eleocharis acutangula (Roxb.) Schult. & A & 15.63 & 10.62 & 19.21 & 12.65 \\
\hline & E. interstincta (Vahl) Roem. \& Schult. & $\mathrm{E} / \mathrm{A}$ & 0.56 & 0.39 & 0.55 & 0.53 \\
\hline & E. minima Kunth & A & 0.33 & 0.72 & 2.51 & 2.46 \\
\hline & E. plicarhachis (Griseb.) Svenson & $\mathrm{E} / \mathrm{A}$ & 0.16 & 0.2 & 0.25 & 0.53 \\
\hline & Fuirena incompleta Nees & A & 0.15 & 0.07 & 0.16 & 0.09 \\
\hline & Rhynchospora corymbosa (L.) Britton & $\mathrm{A} / \mathrm{E}$ & 1.56 & 0.85 & 2.56 & 1.14 \\
\hline & R. cyperoides Mart. & $\mathrm{A} / \mathrm{E}$ & 1.9 & 1.04 & 4.63 & 1.93 \\
\hline & R. trispicata (Nees) Schrad. ex Steud. & $\mathrm{A} / \mathrm{E}$ & 3.48 & 4.11 & 2.13 & 2.9 \\
\hline & R. velutina (Kunth) Boeckeler & $\mathrm{A} / \mathrm{E}$ & 2.27 & 2.93 & 5.63 & 3.87 \\
\hline & Scleria microcarpa Nees ex Kunth & $\mathrm{A} / \mathrm{E}$ & 0.16 & 0.39 & 0.06 & 0.18 \\
\hline \multirow[t]{2}{*}{ ERIOCAULACEAE } & Eriocaulon modestum Kunth & $\mathrm{FF}$ & 0.45 & 0.85 & . & . \\
\hline & *E. setaceum $\mathrm{L}$ & $\mathrm{FF} / \mathrm{E}$ & . & . & . & . \\
\hline EUPHORBIACEAE & Caperonia castaneifolia (L.) A. St.-Hil. & $\mathrm{A} / \mathrm{E}$ & 1.01 & 4.3 & 1.46 & 5.18 \\
\hline \multirow[t]{3}{*}{ FABACEAE } & Aeschynomene filosa Mart. ex Benth. & $\mathrm{A} / \mathrm{E}$ & 1.13 & 2.22 & 0.18 & 0.7 \\
\hline & A. fluminensis Vell. & $\mathrm{A} / \mathrm{E}$ & 2.62 & 4.04 & 3.64 & 6.06 \\
\hline & A. sensitiva $\mathrm{Sw}$. & A & 0.09 & 0.39 & 0.29 & 0.26 \\
\hline HYDROCHARITACEAE & Najas microcarpa K. Schum. & SF & 0 & 0.07 & . & . \\
\hline HYDROLEACEAE & Hydrolea spinosa $\mathrm{L}$. & $\mathrm{A} / \mathrm{E}$ & 0.01 & 0.07 & 0.04 & 0.09 \\
\hline \multirow[t]{2}{*}{ ISOETACEAE } & * Isöetes panamensis Maxon \& C.V. Morton & SF/A & . & . & . & . \\
\hline & I. pedersenii H.P. Fuchs ex Hickey & $\mathrm{SF} / \mathrm{A}$ & 0.08 & 0.39 & 0.08 & 0.09 \\
\hline LAMIACEAE & Hyptis microphylla Pohl ex Benth. & A & 0.12 & 0.2 & 0.1 & 0.18 \\
\hline \multirow[t]{3}{*}{ LENTIBULARIACEAE } & Utricularia foliosa $\mathrm{L}$. & SL & 2.57 & 1.24 & . & . \\
\hline & U. gibba $\mathrm{L}$. & SL & 0.04 & 0.98 & . & . \\
\hline & U. hydrocarpa Vahl & SL & 7.25 & 3.06 & 0.12 & 0.09 \\
\hline
\end{tabular}




\begin{tabular}{|c|c|c|c|c|c|c|}
\hline \multirow[t]{2}{*}{ Family } & \multirow[t]{2}{*}{ Species } & \multirow[t]{2}{*}{$\begin{array}{l}\text { Life } \\
\text { Form }\end{array}$} & \multicolumn{2}{|c|}{$\begin{array}{l}\text { Flood } \\
\text { Season }\end{array}$} & \multicolumn{2}{|c|}{$\begin{array}{c}\text { Dry } \\
\text { Season }\end{array}$} \\
\hline & & & $\mathbf{R C}$ & $\mathbf{R F}$ & $\mathbf{R C}$ & $\mathbf{R F}$ \\
\hline & U. myriocista A. St.-Hil. \& Girard & SL & 7.19 & 2.74 & . & . \\
\hline & *U. olivacea C. Wright & SL & $\cdot$ & . & . & . \\
\hline \multirow[t]{2}{*}{ MALVACEAE } & Byttneria palustris Cristóbal & $\mathrm{A} / \mathrm{E}$ & 0.15 & 0.59 & 0.05 & 0.18 \\
\hline & Melochia simplex A. St.-Hil. & $\mathrm{A} / \mathrm{E}$ & 0.43 & 1.17 & 0.44 & 1.14 \\
\hline MAYACACEAE & Mayaca sellowiana Kunth & $\mathrm{A} / \mathrm{SF}$ & 2.44 & 2.74 & 1.29 & 1.85 \\
\hline MELASTOMATACEAE & Acisanthera alsinaefolia (DC.) Triana & $\mathrm{A} / \mathrm{SF}$ & 0.33 & 0.52 & 0.3 & 0.79 \\
\hline MENYANTHACEAE & Nymphoides indica (L.) Kuntze & $\mathrm{FF}$ & 1.21 & 3 & 1.03 & 2.72 \\
\hline \multirow[t]{3}{*}{ ONAGRACEAE } & Ludwigia filiformis (Micheli) Ramamoorthy & A & 0.08 & 0.33 & 0.1 & 0.26 \\
\hline & L. irwinii Ramamoorthy & A & 0.19 & 0.52 & 0.12 & 0.26 \\
\hline & L. nervosa (Poir.) H. Hara & A & . & . & 0.11 & 0.18 \\
\hline PHYLLANTHACEAE & Phyllanthus stipulatus (Raf.) G.L. Webster & $\mathrm{A} / \mathrm{E}$ & 0.49 & 1.43 & 0.4 & 0.62 \\
\hline \multirow[t]{3}{*}{ PLANTAGINACEAE } & Bacopa australis V. C. Souza & $\mathrm{A} / \mathrm{SF}$ & 0.25 & 0.78 & 0.12 & 0.26 \\
\hline & B. monnierioides (Cham.) B.L. Rob. & $\mathrm{A} / \mathrm{SF}$ & 0.34 & 0.72 & 0.46 & 0.88 \\
\hline & B. reflexa (Benth.) Edwall & SF & 8.62 & 4.63 & . & . \\
\hline \multirow[t]{15}{*}{ POACEAE } & Andropogon bicornis $\mathrm{L}$. & A & 0.39 & 0.2 & 0.36 & 0.18 \\
\hline & A. hypogynus Hack. & $\mathrm{A} / \mathrm{E}$ & 0.01 & 0.07 & & \\
\hline & Imperata tenuis Hack. & $\mathrm{A} / \mathrm{E}$ & 4.75 & 2.54 & 7.46 & 3.95 \\
\hline & Leersia hexandra $\mathrm{Sw}$. & $\mathrm{A} / \mathrm{E}$ & 3.7 & 8.34 & 8.2 & 10.54 \\
\hline & Luziola fragilis Swallen & FF & 3 & 2.8 & 0.06 & 0.18 \\
\hline & Panicum cyanescens Nees ex Trin. & FF & 0.01 & 0.13 & & . \\
\hline & P. parvifolium Lam. & A & 0.73 & 0.98 & 0.44 & 0.7 \\
\hline & P. pedersenii Zuloaga & $\mathrm{A} / \mathrm{E}$ & 0.09 & 0.2 & 0.25 & 0.35 \\
\hline & $\begin{array}{l}\text { Paspalum morichalense Davidse, } \\
\text { Zuloaga \& Filg. }\end{array}$ & $\mathrm{A} / \mathrm{FF}$ & 0.09 & 0.46 & 0.56 & 0.97 \\
\hline & P. lenticulare Kunth & $\mathrm{A} / \mathrm{E}$ & 8.37 & 2.67 & 9.77 & 3.69 \\
\hline & Rhytachne rottboellioides Desv. & $\mathrm{A} / \mathrm{E}$ & 2.23 & 1.17 & 1.84 & 1.05 \\
\hline & Saccharum asperum (Nees) Steud. & $\mathrm{A} / \mathrm{E}$ & 0.28 & 0.2 & 0.73 & 0.26 \\
\hline & S. villosum Steud. & $\mathrm{A} / \mathrm{E}$ & 0.75 & 0.33 & 0.44 & 0.35 \\
\hline & Sacciolepis vilvoides (Trin.) Chase & $\mathrm{A} / \mathrm{E}$ & 0.66 & 0.33 & 1.05 & 0.53 \\
\hline & Steinchisma laxum (Sw.) Zuloaga & A & 0.05 & 0.26 & & . \\
\hline \multirow[t]{2}{*}{ PONTEDERIACEAE } & Pontederia cordata $\mathrm{L}$. & $\mathrm{E}$ & 0.15 & 0.33 & 0.3 & 0.35 \\
\hline & P. parviflora Alexander & $\mathrm{E}$ & 0.2 & 0.2 & 0.93 & 0.53 \\
\hline \multirow[t]{2}{*}{ RUBIACEAE } & Borreria pulchristipula (Bremek.) & $\mathrm{E}$ & 0.01 & 0.07 & . & . \\
\hline & Bacigalupo \& E.L. Cabral & & & & & \\
\hline SOLANACEAE & Schwenckia juncoides Chodat & $\mathrm{A} / \mathrm{E}$ & 1.06 & 4.11 & 2.14 & 4.31 \\
\hline THELYPTERIDACEAE & Thelypteris serrata (Cav.) Alston & $\mathrm{A} / \mathrm{E}$ & 0.34 & 0.59 & 1.05 & 0.97 \\
\hline XYRIDACEAE & Xyris laxiflora F. Muell. & $\mathrm{A} / \mathrm{E}$ & 0.28 & 0.52 & 0.22 & 0.44 \\
\hline
\end{tabular}

and relative frequency (RF) was $53.2 \%$, whereas in the dry season RC was $71 \%$ and RF was $64.1 \%$. The species with highest $\mathrm{RC}$ in the rainy season were Eleocharis acutangula (15.6\%), Bacopa reflexa (8.6\%), Paspalum lenticulare $(8.3 \%)$ and Utricularia hydrocarpa (7.2\%), and in the dry season E. acutangula (19.2\%), P. lenticulare (9.7\%), Leersia hexandra (8.2\%) and Imperata tenuis $(7.4 \%)$. Probably $B$. reflexa and $U$. hydrocarpa, which are true aquatic species, were replaced by the amphibious L. hexandra and Imperata tenuis, among the ten species with the highest RC (Tab. 1). Eleocharis acutangula was sampled in both seasons, and showed RC of $15.6 \%$ in the rainy season and $19.2 \%$ in the dry season. We observed that the RC of E. acutangula 


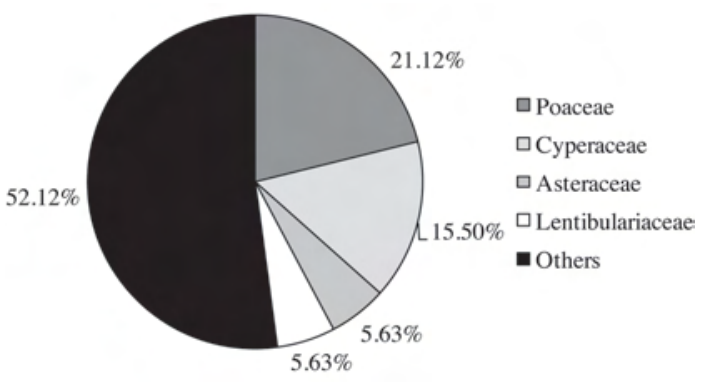

Figure 1 - Richest families in the pond associated to a vereda, Terenos, MS, Brazil.

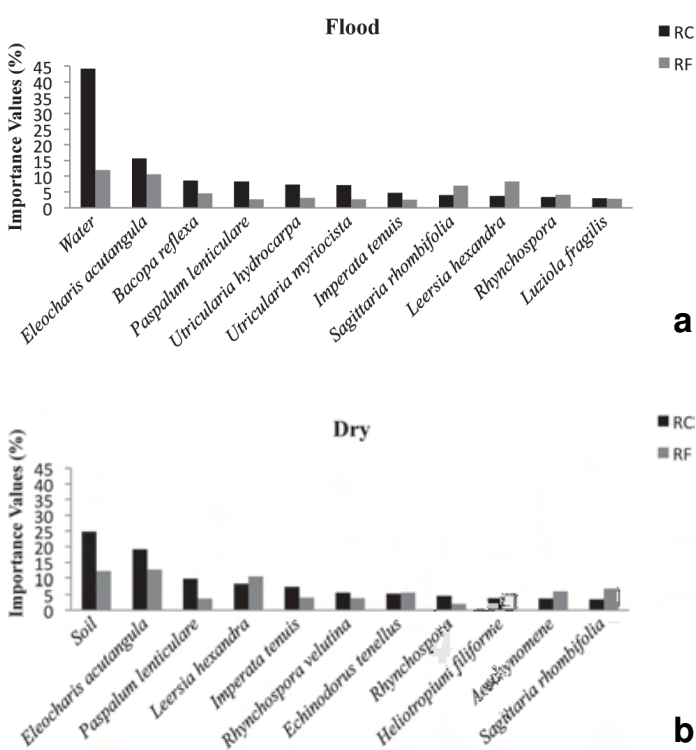

Figure 2 - Species with highest Importance Values (IV) in the sampled pond associated to vereda in Terenos, MS, Brazil in the flood (a) and dry (b) seasons. The black bars mean relative cover and gray bars relative frequency.

increased in the dry season, because it became prostrated and drainage-flow-orientated after the water receded. In the study carried out by Rebellato $\&$ Nunes da Cunha (2005) in a floodable grassland in the Pantanal, E. acutangula had the eighth highest $\mathrm{RC}$ and $\mathrm{RF}$ in the rainy season, and ranked tenth in the dry season.

Figure 2 shows high RC values for water surface in the rainy season and for soil in the dry season, as expected. Sagittaria rhombifolia and Leersia hexandra occurred in most of the study area in both seasons, though they did not contribute to high relative cover, whereas Bacopa reflexa,
Paspalum lenticulare, Utricularia hydrocarpa, $U$. myriocista, Imperata tenuis and Rhynchospora velutina showed a more restricted distribution (in patches), but occupied larger areas. Bacopa reflexa, $U$. hydrocarpa and U. myriocista are waterdependent species and therefore do not survive in dry habitats for long periods, whereas $P$. lenticulare, $L$. hexandra, I. tenuis and $R$. velutina are amphibious species that can establish themselves in a flooded habitat, with vigorous growth or endure flood periods, as well as grow on dry ground.

In the rainy season, with higher species richness, the indexes were higher, $\mathrm{H}^{\prime}=3.25$ and $\mathrm{J}^{\prime}$ $=0.76$, compared to $\mathrm{H}^{\prime}=2.00$ and $\mathrm{J}^{\prime}=0.49$ in the dry season. For Saporetti Jr. et al. (2003), a Shannon index above 3.11 indicates wellconserved habitats. Rebellato \& Nunes da Cunha (2005), in a floodable grassland in the Pantanal, obtained Shannon values of 4.01 (rainy season) and 3.29 (dry season), and attributed the higher diversity during the rainy season to low flood intensity, which allows the establishment of amphibious and aquatic species. This can also explain the low value of the index for the dry season in our study area. The evenness index was higher in the rainy season, as there were only a few dominant species. The low value in the dry season indicates better-distributed species abundances.

Sørensen similarity index was extremely high between seasons (0.85), probably because it was measured for the same area in different seasons. The high representativeness of amphibious species, with values over $68 \%$, can explain the high value of this index. Similarity was low (9.6\%) when compared to the species of the lower zone of the vereda (permanently flooded) reported by Araújo et al. (2002); the authors found 137 species, but only 10 were common to our study. Their study pointed to Mayacaceae and Hydrocharitaceae as mainly aquatic, however we did not find the latter.

Water depth varied from 41 to $111 \mathrm{~cm}$ in the rainy season, whereas in the dry season the pond dried and the water table was deeper than $70 \mathrm{~cm}$ except for a small $15 \mathrm{~cm}$ deep remaining pool.

Species were grouped by depth for the five transects (Fig. 3), thus providing an overview of all species with cover over $20 \%$ distributed at all depths, showing that Eleocharis interstincta, Cabomba furcata, Pontederia parvifolia, Utricularia foliosa and Bacopa australis occur mainly in the deepest zones, whereas Acisanthera alsinaefolia, Andropogon bicornis, Saccharum 


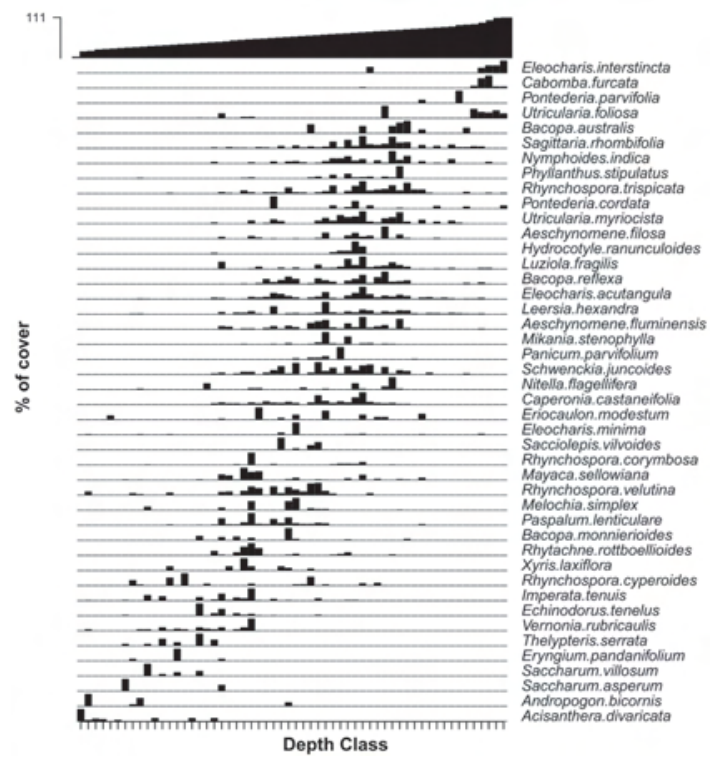

Figure 3 - Ordination of cover percentage values and general distribution of species with cover above $20 \%$ in the studied pond by function of water depth gradient, associated to vereda, Terenos, MS. The black bar at the top corresponds to the depth profile of the pond.

asperum, S. villosum, Eryngium pandanifolium and Thelypteris serrata occur mainly in shallower waters. Figure 4 shows the ordination of species with less than $20 \%$ cover. Paspalum morichalense occurred in the deepest zones, whereas Ludwigia nervosa, Fuirena incompleta, Eleocharis plicarhachis and Borreria pulchristipula occurred in the shallowest zones. In aquatic habitats plants are generally distributed in water depth zones (Pott $\&$ Pott 2003), and this pattern was observed in the species ordination according to water depth. Most species were distributed gradually from the shallowest to the deepest levels. However, some plants were spread along different depths, such as Steinchisma laxum and Aeschynomene sensitiva, which were present everywhere in the pond.

The ordination through DCA of the five sampled transects in the ponds in the dry season corroborated the ordination in $\mathrm{R}$, which exhibited high eigenvalues for both first axes ( 0.72 for the first axis and 0.16 for the second). The first two axes of DCA explained $88 \%$ of the variation. Over $70 \%$ of this variation was explained by the first axis, which

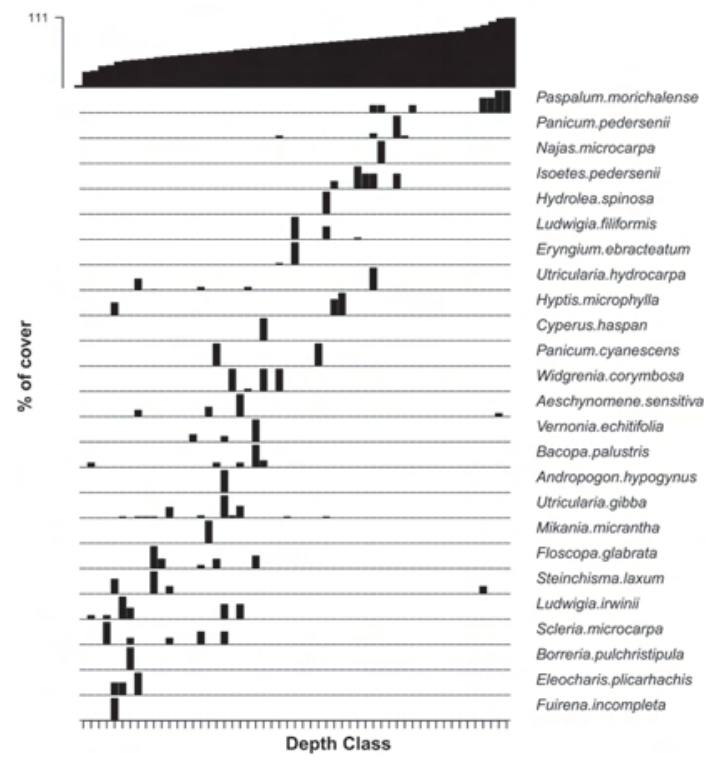

Figure 4 - Ordination of cover percentage values and general distribution of species with cover below $20 \%$ in the studied pond by function of water depth gradient, associated to vereda, Terenos, MS. The black bar at the top corresponds to the depth profile of the pond.

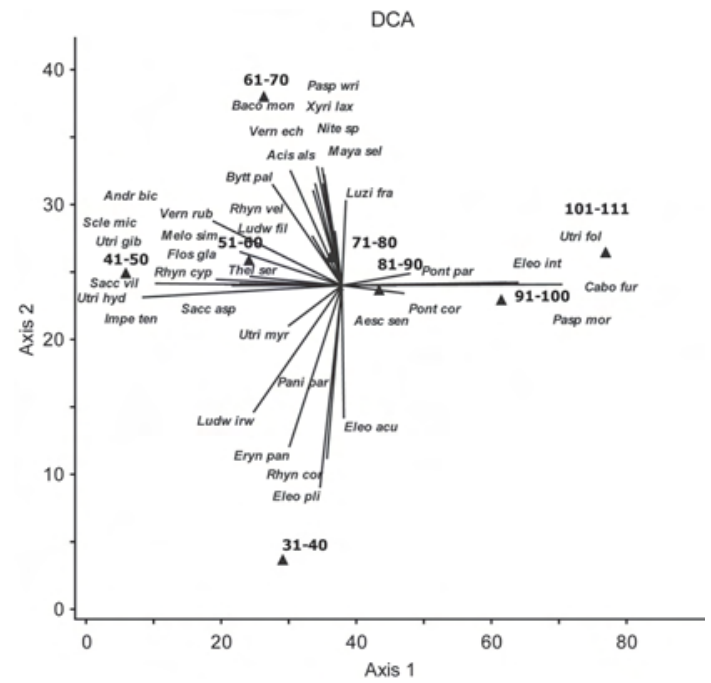

Figure 5 - Ordination of the species through Detrended Correspondence Analysis (DCA), sampled in five lines in the pond, by water depth, in vereda, Terenos, MS. The triangles show the classes of water depth. Axis $1=0.72$ and Axis $2=0.16$. 
separated the species $U$. foliosa, $P$. morichalense, $E$. interstincta and $C$. furcata in the deepest zone, as they are truly aquatic plants. Eleocharis acutangula, E. plicarhachis, Rhynchospora corymbosa, Eryngium pandanifolium, Ludwigia irwinii and Panicum parvifolium occurred in the shallowest zone, and the other species remained in intermediate zones (Fig. 5).

\section{Acknowledgements}

CAPES granted the first author a scholarship and the second author a senior professor grant; Embrapa gave us access to the area and kept firebreaks; the graduate school of UFMS funded our study.

\section{References}

APG-III. 2009. An update of the Angiosperm Phylogeny Group classification for the orders and families of flowering plants: APG III. The Linnean Society of London, Botanical Journal of the Linnean Society 161: 105-121.

Araújo, G.M.; Barbosa, A.A.; Arantes, A.A. \& Amaral, A.F. 2002. Composição florística de veredas no município de Uberlândia, MG. Revista Brasileira de Botânica 25: 475-493.

Bove, C.P.; Bragança-Gil, A.S.; Moreira, C.B. \& Anjos, R.F.B. 2003. Hidrófitas fanerogâmicas de ecossistemas aquáticos temporários da planície costeira do estado do Rio de Janeiro, Brasil. Acta Botanica Brasilica 17:119-135.

Brower, J.E. \& Zar, J.H. 1984. Field and laboratory methods for general ecology. $2^{\text {nd }}$ ed. W.C. Brown Publishers, Iowa. 226p.

Casanova, M.T. \& Brock, M.A. 2000. How do depth, duration and frequency of flooding influence the establishment of wetland plant communities? Plant Ecology 147: 237-250.

Esteves, F.A. 1998. Fundamentos de limnologia. Interciência/FINEP, Rio de Janeiro. 602p.

Gil, A. S. B. \& Bove C. P. 2004. O gênero Eleocharis R. Br. (Cyperaceae) nos ecossistemas aquáticos temporários da planície costeira do estado do Rio de Janeiro. Arquivos do Museu Nacional 62: 131-150.

Guimarães, A.J.M.; Araújo, G.M. \& Corrêa, G.F. 2002. Estrutura fitossociológica em área natural e antropizada de uma veredas em Uberlândia, MG. Acta Botanica Brasilica 16: 317-330.

Irgang, B.E.; Pedralli, G. \& Waechter, J.L. 1984. Macrófitos aquáticos da Estação Ecológica do Taim, Rio Grande do Sul, Brasil. Roessléria 6: 395-404.

Junk, W.J.; Bayley, P.B. \& Sparks, R. E. 1989. The flood pulse concept in river-floodplain systems. In.: Dodge, D.P. (ed.). Proceedings of International Large River
Symposium. Canadian Special Publication of Fisheries and Aquatic Sciences 106: 110-127.

Kent, M. \& Coker, P. 1992. Vegetation description and analysis. A practical approach. John Willey, Chichester; CRC Press/Bellueveu Press, London. 363p.

Keddy, P.A. 2000. Wetland ecology: principles and conservation. Cambridge University Press, Cambridge. 614p.

Köppen, W. 1984. Climatologia. Fondo de Cultura Económica, Ciudade de México. 213p.

Krause, W. 1997. Ciudad Charales (Charophyceae). In: Ettl, H.; Gärtner, G.; Heyning, H. \& Molenhauser, D. (eds.). Subwasserflora von Mitteleuropa. Vol. 18. Gustav Fischer Verlag, Sttutgart. 202p.

Meirelles, M.L.; Oliveira, R.C.; Ribeiro, J.F.; Vivaldi, L.J.; Rodrigues, L.A. \& Silva, G.P. 2002. Utilização do método de interseção na linha em levantamento quantitativo do estrato herbáceo do cerrado. Boletim do Herbário Ezechias Paulo Heringer 9: 60-68.

Meirelles, M.L.; Guimarães, A.J.M.; Oliveira, C.O.; Araújo, G.M. \& Walter, J.F. 2004. Impactos sobre o estrato herbáceo de áreas úmidas do cerrado. In: Aguiar, L.M.S. \& Camargo, A.J.A. (eds.). Cerrado: ecologia e caracterização. Embrapa Cerrados, Brasília. Pp. 41-68.

Mueller-Dombois, D. \& Ellenberg, H. 1974. Aims and methods of vegetation ecology. John Wiley \& Sons, New York. 547p.

Munhoz, C.B.R. \& Felfili, J.M. 2008. Fitossociologia do estrato herbáceo-subarbustivo de um campo limpo úmido no Brasil Central. Acta Botanica Brasilica 22: 905-913.

Oliveira, G.C.; Araujo, G.M. \& Barbosa, A.A.A. 2009. Florística e zonação de espécies vegetais em veredas no Triângulo Mineiro, Brasil. Rodriguésia 60: 1077-1085.

Pott, V.J; Bueno, N.C.; Pereira, R.A.C.; Salis, S.M. \& Vieira, N.L. 1989. Distribuição de macrófitas aquáticas numa lagoa na Fazenda Nhumirim, Nhecolândia, Pantanal, MS. Acta Botanica Brasilica 3: 153-168.

Pott, V.J; Bueno, N.C. \& Silva, M.P. 1992. Levantamento florístico e fitossociológico de macrófitas aquáticas em lagoas da Fazenda Leque, Pantanal, MS. Anais do VIII Congresso da Sociedade Botânica de São Paulo. Pp. 91-99.

Pott, V.J. \& Pott, A. 2000. Plantas aquáticas do Pantanal. Embrapa, Corumbá. 404p.

Pott, V.J. \& Pott, A. 2003. Dinâmica da vegetação aquática do Pantanal. In: Thomaz, S. M. \& Bini, L.M. (eds.). Ecologia e manejo de macrófitas aquáticas. EDUEM, Maringá. Pp. 145-162.

Pott, V.J.; Pott, A.; Lima, L.C.P.; Moreira, S.N. \& Oliveira, A.K.M. 2011. Aquatic macrophyte diversity of the Pantanal wetland and upper basin. Brazilian Journal of Biology 77: 255-263. 
R Development Core Team. 2009. R: a language and environment for statistical computing. R Foundation for Statistical Computing, Vienna. Available in <http:// www.R-project.org>. Access on 17 Jun 2011.

Rebellato, L. \& Nunes da Cunha, K. 2005. Efeito do "fluxo sazonal mínimo da inundação" sobre a composição e estrutura de um campo inundável no Pantanal de Poconé, MT, Brasil. Acta Botanica Brasilica 19: 789-799.

Rosa, J.G. 2001. Grande sertão: veredas. 19 ed. Nova Fronteira, Rio de Janeiro. 608p.

Sano, S. M.; Almeida, S. P. \& Ribeiro, J. F. (org.). 2008. Cerrado: ecologia e flora. Vol. 2. Embrapa, Brasília. $1284 p$.
Saporetti Jr., A.; Meira Neto, J.A. \& Almado, R.P. 2003. Fitossociologia de cerrado sensu stricto no município de Abaeté, MG. Revista Árvore 27: 413-419.

Sousa, F.D.R. \& Elmoor-Loureiro, L.M.A. 2008. Cladóceros fitófilos (Crustacea, Branchiopoda) do Parque Nacional das Emas, estado de Goiás. Biota Neotropica 8: 159-166.

Tropicos. (2010). Tropicos Home - Missouri Botanical Garden. Available in <http://www.tropicos.org>. Access on 20 Jun 2011.

Tryon, R.M. \& Tryon, A.F. 1982. Ferns and allied plants, with special reference to Tropical America. Springer Verlag, New York. 857p. 